\title{
Understanding The Canadian Foreign Policy Ratified Comprehensive and Progressive Agreement for Trans-Pacific Partnership (CPTPP) in 2018
}

\author{
${ }^{1}$ Faturachman Alputra $S,{ }^{2}$ Syastri Wulandari \\ ' Program Studi IImu Pemerintahan, FISIP, Universitas Halu Oleo \\ , 2 Jurusan Administrasi Publik, FISIP, Universitas Halu Oleo \\ E-mail: fatur@uho.ac.id \\ Kendari - Indonesia
}

\begin{abstract}
Abstract: In 2018, Canada decided to ratify one of the Free Trade Agreement in the Asia Pacific Region, it was the Comprehensive and Progressive Agreement for Trans-Pacific Partnership (CPTPP). This study aims to analyse Canadian policy to join in the CPTPP use Neoliberalism approach by Balaam \& Veseth (2005) to see the benefits gained from the free trade agreement. As well as the national interest concept from Nuechterlein (1976) to analyse the interests of Canada in ratified CPTPP in 2018. This research method uses qualitative descriptive, where data was collected through interviews and documentation. The results of this study conclude that the policy to ratified the agreement based on economic interests where Canada can diversify export markets, achieve tariff elimination and market expansion.
\end{abstract}

\section{Keywords: Canada; Foreign Policy; National Interest; CPTPP}

Open Access at: http://ojs.uho.ac.id/index.php/PUBLICUHO/index

Journal Publicuho is licensed under a Creative Commons Attribution 4.0 International License.

\section{INTRODUCTION}

In 2018, 11 countries signed the Asia-Pacific Comprehensive and Progressive Agreement for the Trans-Pacific Partnership (CPTPP), a multilateral free trade agreement formerly known as the Trans-Pacific Partnership (TPP). Replacing the TPP agreement in which the US has withdrawn from membership, the CPTPP is a significant step towards closer trade and investment relations in the Asia-Pacific region and setting high new standards for regional trade.

Previously, In 2008, the Trans-Pacific Strategic Economy Partnership (TPSEP) changed its name to Trans-Pacific Partnership (TPP) and gained several new member countries such as the United States, Peru, Australia and Vietnam. Followed by the joining of Malaysia in 2010, Mexico and Canada in 2012. Before Canada finally officially joined in 2012, Canada had difficulty entering the negotiating table, because previously Canada had received an offer to enter into the negotiation process at the beginning of the TPP, but Canada refused. Until 2010, Canada began to show its desire to be part of the TPP by becoming involved in the negotiation process as an observer. 
Dynamics of economic growth Asia Pacific region make Canada attract in this region, Economic growth in this region which continues to grow after the crisis that occurred in 2009, make this region was born as the new emerging power (Cossa et al., 2009). In addition, the joining of several large countries such as Australia, Peru and several other countries was a factor in the need for Canada to participate in the TPP, because although the relations established between Canada and several countries in the Pacific region, especially Australia, were classified as fluctuating, there was no binding agreement so that the TPP is a Canadian instrument for reaching these countries.

However, in early 2017, the stability of the role of this partnership agreement began to be doubted since the United States left the membership remained under the leadership of President Donald Trump. Doubt arises because the United States as the prime mover in the global trade liberalisation of countries in the Asia Pacific region is now beginning to devise a new policy, namely America first, where multilateral-based partnerships with other countries will be very difficult to realise compared to bilateral cooperation. (CNN Indonesia, 2017).

Protectionism by the United States has significantly reduced the percentage of profits from member countries. The enormous role of the United States in the TPP Partnership Agreement is based on its strength in building market openings based on economic sector reform. TPP partnership agreements provide broader space in the form of trade access to developing countries to the markets of the United States, Japan and Australia. International trust in the effectiveness of the TPP has worsened due to criticism from academics and the domestic economy in various countries. (Anjani, 2018). The most significant criticism of the TPP was the form of an agreement containing three elements of neoliberalism practices: free trade of goods and services, free circulation of capital, and freedom of investment. Public opinion about TPP's bad reputation has been widely circulated both at national and international levels, which has made TPP's condition worsens after the resignation of permanent membership by the United States so that it becomes increasingly unstable with the issue of neoliberal practices that position investors from various large corporations above interests of society and the State.

The exit of the United States from membership, as well as the growing public opinion polemic about the inadequate system of the Trans-Pacific Partnership, did not change Japan's belief in continuing to place great trust in the potential for cooperation initiated by the initial trade agreement, TPSEP. Japan then set a new formulation of the TPP economic regional-based regional partnership agreement to become a Comprehensive and Progressive Agreement for the Trans-Pacific Partnership (CPTPP), convincing the other ten member countries. CPTPP without the United States is still the most significant free trade agreement in the world, CPTPP is one of the largest free trade agreements in the world, representing nearly 13.5 per cent of global gross domestic product (GDP). The agreement 
links 11 Asia-Pacific economies-Australia, Brunei, Canada, Chile, Japan, Malaysia, Mexico,

New Zealand, Peru, Singapore, and Vietnam-providing freer trade and investment access among its members. (Goodman, 2018).

CPTPP still must be ratified by member countries to go into effect. From June 2018 to October 2018 six countries were ratifying the CPTPP agreement, including Canada, which became the fifth country to ratify this agreement. The CPTPP text states that the agreement entered into force 60 days after ratification by at least $50 \%$ of the signatories or six of the eleven participating countries. CPTPP was effective on December 30, 2018. Canada's policy in ratifying the CPTPP is inseparable from the national interests. The national interest is the perceived needs and desires of one sovereign state in relation to other sovereign states comprising the external environment. Nuechterlein (1976) classifies national interests into four categories. That's are defence Interest, economic interest, world order interest, and ideological interest. This study will analyse Canada economic interest to make policy ratified CPTPP in 2018. Foreign policy can be understood as a way to articulate and struggle for national interests (Brown, 2005).CPTPP is an opportunity for Canada to increase access to fast-growing Asia-Pacific markets and to benefit from eliminating some tariffs between treaty partners. Access to the Asia-Pacific region market will allow Canada to be the only G7 country with preferential trade access to the United States, to the European Union, and the Asia-Pacific market. The Canadian government expects several economic sectors to benefit from CPTPP. Therefore, ratified CPTPP agreements, Canada will gain from market liberalisation through tariff elimination. Neoliberalism emphasises market deregulation and international market liberalisation.(Balaam \& Veseth, 2005)

\section{METHOD}

This study uses descriptive research methods with a qualitative approach. Bodgan and Taylor define qualitative research as research that produces descriptive data in the form of written or oral words from people and observable behaviour. The collection technique was carried out using two methods: First, an interview via email conducted to Indonesian Consulate General in Toronto Canada, Second: Documentation, collected through the collection of government documents, books, journals, academic study results, and mass media articles. The data analysis method used is an interactive model analysis that is using data collection, data reduction, data presentation, and conclusions (Miles \& Huberman, 2007). The research focus is the interests of the Canadian Economy in ratifying the Comprehensive and Progressive Agreement for the Trans-Pacific Partnership (CPTPP) in 2018. 


\section{ANALYSIS AND DISCUSSION \\ From Trans-Pacific Partnership (TPP) To Comprehensive and Progressive Agreement for Trans- Pacific Partnership (CPTPP)}

TPP is a significant agreement that has never existed before, TPP is an agreement that aims to liberalise trade in goods, services and investment and to overcome trade problems that have arisen in the 21 st century such as non-tariff barriers, transparency, etc. The Trans-Pacific Partnership (TPP) is a cooperation agreement that began with a special trade agreement called the Trans-Pacific Strategic Economic Partnership (TPSEP), by several countries such as the United States, Chile, Singapore, Australia and New Zealand. The five countries held an informal negotiation on the establishment of trade cooperation in the Asia Pacific region. However, at the next meeting which took place in 2002, in Los Cabos, Mexico, only Singapore, Chile and New Zealand continued the negotiations. The three countries resumed negotiations in 2003 in Singapore and appointed Brunei Darussalam to participate in the talks to become an observer at the negotiations held in New Zealand, in 2004. Furthermore, In 2005 Brunei Salam officially decided to join, as well as being the founder of TPSEP. (Elms \& S, Lim, 2012).

The Trans-Pacific Partnership was developed from the Trans-Pacific Economic Partnership Agreement (P4) between Brunei, Chile, New Zealand and Singapore in 2006. The agreement contains aspects of the past trade agreements on agriculture, forestry, fisheries and industrial goods where tariff reductions and/or eliminations have been negotiated while incorporating new areas such as electronic commerce.(Mukhopadhyay \& Thomassin, 2018). Although discussions continue, TPSEP did not get additional members until 2008. The United States announced its intention to join. After joining the United States, TPSEP changed its name to Trans-Pacific Partnership (TPP). The joining of the United States with TPSEP is seen as a catalyst for Asia Pacific countries because a few months after the United States announced its decision, Australia, Peru and Vietnam also announced their interest in joining. The TPSEP negotiation process was resumed, and in 2010, TPSEP changed to TPP, along with Malaysia's joining the negotiation process.

The exit of the United States from the membership of the TPP became a polemic of public opinion that developed about the weak system of the Trans-Pacific Partnership. But this did not change membership intention such as Japan, to continue to place great trust in the potential for cooperation initiated by the initial trade agreement, TPSEP. Japan sees excellent potential for the TPP partnership that accommodates economic integration to maintain the stability and security of the Asia Pacific region. Under the new TPP formulation, Japan believes in the development of a multilateral security frame to strengthen the value of the Asia Pacific alliance. The new TPP partnership is not only a new alternative for the regional economy but also the potential for integrated development in the security and 
defence sector. Japan then initiated a meeting with eleven TPP member countries at the APEC summit meeting in Vietnam in November 2017, as a form of moral responsibility to the Japanese public for its decision to ratify the TPP Agreement in 2016. (The Straits Times, 2017). This meeting resulted in a decision to continue the TPP without US participation by formulating regulations new regulations to gain the trust of the international community.

The formulation of the new TPP agreement was held in Tokyo on January 23, 2018, by setting a further evaluation of the TPP regional economic-based partnership agreement to be a Comprehensive and Progressive Agreement for Trans-Pacific Partnership (CPTPP) by convincing the governments of Australia and Canada. This new formulation was finally signed by six other member countries in March 2018 in Santiago, with the addition of an article that considers the submission of personal rights of each company in the Member States to regulate and determine policies independently. The CPTPP partnership includes new regulations that are more transparent compared to TPP in the field of labour, the environment, and the elimination of tariff and non-tariff barriers so that in the future it is expected to reduce the suspicion of the international community. In addition to anticipating rejection from domestic communities, the formulation of CPTPP is more cooperative towards the desires of member countries, especially in the company's personal rights policy which is expected to be able to attract several countries in Asia, especially Thailand, Indonesia, and South Korea. (Leong, 2018)

There were several views that the withdrawal of the United States from the TPP would push countries in the region closer to China, the formation of the CPTPP Agreement demonstrates the determination and economic confidence of these countries. The AsiaPacific region in supporting trade liberalisation, economic integration, and multilateral cooperation with equality and mutual benefit while not overly dependent and controlled by certain markets. In fact, with the TPP Agreement, participating countries are directed at the benefits of the American market, the largest economy in the world. However, even without this economic involvement, CPTPP is still a significant market, promising to bring many benefits to partner countries.(Yen, 2017)

Twelve original TPP signatories are Australia, Brunei, Canada, Chile, Japan, Malaysia, Mexico, New Zealand, Peru, Singapore, the United States, and Vietnam. They are all members of APEC and have a combined population of nearly 825 million, combined GDP of just under the US $\$ 30$ trillion. CPTPP produces about one-third of the total GDP produced by TPP12, accounts for around $60 \%$ of the TPP12 region's population, and has an average per capita of about one-third of the US level, as well as with market exchange rates. (Ciuriak, Xiao, \& Dadkhah, 2017). A brief comparison between the size of the CPTPP and the original TPP shows that the two agreements represent the main trading blocs in the world. The TPP agreement was signed in 2016 with 12 parties, and the Comprehensive and Progressive 
Agreement and the Trans-Pacific Partnership (CPTPP) will cover 11 countries. In terms of scale, the TPP Agreement represents $40 \%$ of GDP, $30 \%$ of global trade and more than 800 million people. The CPTPP agreement represents around 15\% of GDP, $15 \%$ of global trade, and nearly 500 million people. (Estrada, 2016)

Table 1. GDP and CPTPP population data

\begin{tabular}{|c|c|c|c|c|c|}
\hline & \multicolumn{2}{|c|}{ GDP } & \multicolumn{2}{|c|}{ GDP Per Capita } & \multirow{2}{*}{$\begin{array}{c}\text { Population } \\
\text { Millions }\end{array}$} \\
\hline & $\begin{array}{c}\text { Current } \\
\text { US\$ Millions }\end{array}$ & $\begin{array}{c}\text { PPP } \\
\text { US\$ Millions }\end{array}$ & Current US\$ & PPP US\$ & \\
\hline Australia & $1,390,150$ & $1,235,297$ & 56,135 & 49,882 & 24.8 \\
\hline Brunei Darussalam & 11,963 & 32,913 & 27,893 & 76,743 & 0.4 \\
\hline Canada & $1,529,760$ & $1,682,503$ & 42,225 & 46,441 & 36.2 \\
\hline Chile & 263,206 & 452,095 & 14,315 & 24,588 & 18.4 \\
\hline Japan & $4,884,489$ & $5,405,072$ & 38,550 & 42,659 & 126.7 \\
\hline Malaysia & 309,858 & 926,081 & 9,660 & 28,871 & 32.1 \\
\hline Mexico & $1,142,453$ & $2,406,087$ & 9,249 & 19,480 & 123.5 \\
\hline New Zealand & 200,837 & 185,748 & 41,629 & 38,502 & 4.8 \\
\hline Peru & 210,013 & 424,639 & 6,598 & 13,342 & 31.8 \\
\hline Singapore & 305,757 & 513,744 & 53,880 & 90,531 & 5.7 \\
\hline Vietnam & 215,963 & 643,902 & 2,306 & 6,876 & 93.6 \\
\hline СРТРP & $10,464,449$ & $13,908,081$ & 21,010 & 27,923 & 498 \\
\hline Memo: United States & $19,362,129$ & $19,362,129$ & 59,495 & 59,495 & 325.4 \\
\hline TPP12 & $29,826,578$ & $33,270,210$ & 36,218 & 40,400 & 823.5 \\
\hline
\end{tabular}

Source: (International Monetary Fund (IMF), 2017)

\section{Canada Involvement in TPP}

After being an observer in 2010, in 2012, Canada finally decided to join the TPP, also joined Mexico in the same year, and in 2013 followed by Japan which finally decided to join this agreement. Canada hopes that the TPP will be an opening for Canada to enter new markets in the Asia Pacific region, which is currently the region with the fastest economic growth. This opportunity can open up opportunities for Canada to create new jobs, increase export capacity and is expected to bring other positive impacts on the Canadian economy, and strengthen Canada's cooperative relations with various other member countries. (Mukhopadhyay \& Thomassin, 2018)

Canada's joining the TPP requires quite a long time. During the process, protests were made by several domestic social groups who did not agree that Canada joined the TPP, but on the other hand, associations of sectors that have an essential role for the Canadian economy encouraged Canadian efforts to join. The occurrence of pros and cons becomes the government's consideration so that the government collects the preferences of the stakeholder groups that have an essential role in Canada's vital sector, and consults with several parties before finally deciding to join the TPP.

Some domestic associations that refuse Canada to join the TPP are The Council of Canadians, the Green Party of Canada, the Canadian Labor Congress, and Unifor. These 
associations refused because they considered that some of the regulations contained in the TPP were deemed to be detrimental to Canada. First, there is the Investor-State Dispute Settlement (ISDS) regulation. Second, the existence of Intellectual Property Rights (IPR) protection regulations for medicines will afflict the people of Canada because patent medicines have higher prices, and the public will not get access to generic drugs that have more affordable prices. On the other hand, several associations such as The Canadian Service Coalition (CSC), The Canadian Generic Pharmaceutical Association (CGPA), and The Canadian Agri-Food Trade Alliance (CAFTA), support Canada's efforts to join the TPP regarding intellectual property right, furthermore, Canada is a country that relies heavily on trade in goods and services to expand markets, create jobs and provide consumers with a variety of choices at lower prices to improve the standard of living of Canadians. (Aisyah, 2018).

\section{Analysis of Canadian Interest in CPTPP}

Based on the potential possessed by CPTPP member countries, Canada decided to be actively involved in the CPTPP agreement. Canada is one of the countries that adhere to a free trade system, and CPTPP is a great opportunity for the growth and development of Canadian trade. At least Canada's interest in ratifying CPTPP is based on strong economic interests consisting of First, Diversification of export markets. Second, abolition of lower tariffs in the CPTPP Agreement and Third, market expansion or expanding markets in the Asia Pacific region.

\section{Diversification of Export Markets.}

After the withdrawal of the United States, Canada became the second-largest economy in the CPTPP, which exerted more significant influence and made it possible to change the agreement more by its wishes. The exit of the United States from the TPP creates new incentives to push the Canadian economy forward with CPTPP protectionist rhetoric, and the Trump administration's actions have benefited Canada which can strengthen its export market diversification to reduce its significant dependence on the US market.

According to the Indonesian Consulate General of Toronto Canada, Leonard Felix Hutabarat, joining Canada in CPTPP, Canada wanted to reduce dependence on the United States by strengthening export market diversification. So CPTPP is expected to provide benefits to the Canadian economy as a result of increased market access and greater regional economic integration with Asia-Pacific countries.(Hutabarat, 2019). CPTPP is a trade agreement that includes digital commerce, intellectual property rights, State-owned companies and nontariff barriers. CPTPP is projected to increase Canadian GDP by $\$ 4.2$ billion in the long run rather than under the TPP which only increases GDP to $\$ 3.4$ billion. (Office of the Chief Economist Global Affairs Canada, 2018a). So that CPTPP can provide Canada with more 
opportunities for export diversification and brand investment that is profitable for Canada trade.

\section{Enhancing and Maintaining Market Access in the Asia Pacific Region through the Tariffs Elimination in the CPTPP Agreement.}

CPTPP results in the elimination of comprehensive tariffs in all sectors. Once fully implemented, 99\% of the tariff lines among CPTPP members are will be duty-free. The CPTPP does this by requiring signatories to implement an unprecedented rate cut (i.e. removing more than $95 \%$ of the tariff line for more than $98 \%$ of total trade between members). CPTPP provides the advantage of market access because of elimination of tariff barriers that offer new opportunities for Canadian exporters in various sectors in traditional markets, including Japan and Vietnam. This situation can provide a competitive advantage for several Canadian products such as:

First, Agriculture. Canada Agriculture and Agri-food products. Exports currently face high tariffs. After the enactment of CPTPP, more than three-quarters of Canada's agricultural and food products will benefit from direct duty-free access of around $94 \%$ of exports of agricultural products and agricultural food. (Office of the Chief Economist Global Affairs Canada, 2019) Second, fish and seafood product. CPTPP will create new export opportunities through the elimination of tariffs and regulations on technical barriers to trade and protection of sanitation and phytosanitary. Under this agreement will allow an increase in fish and seafood products. Canadian fish and seafood exports will benefit compared to countries that do not have free trade agreements or have unprofitable access to CPTPP. When CPTPP comes into force, around $66 \%$ of Japan's entry tariffs, nearly $83 \%$ of Vietnam's low tariffs and $100 \%$ of Malaysia's low tariffs for fish and seafood will be duty-free, with the remainder to be removed within 15 years. (Office of the Chief Economist Global Affairs Canada, 2018c). Third, Forest products. CPTPP will eliminate all tariffs on forests and value-added wood products, creating new opportunities for Canada's main exports. Through eliminating tariffs and establishing clear and transparent trade rules. CPTPP will create new export opportunities in key markets such as Malaysia, Japan and Vietnam. Canada is currently the largest supplier of forest products and wood value added to Japan, with an average export of $\$ 1.7$ billion from 2014 to 2016. Under the CPTPP Agreement, Canadian forestry exports will have an advantage over exports in areas outside the CPTPP free trade, like Russia and China.(Office of the Chief Economist Global Affairs Canada, 2018d). Fourth, industrial products. Tariff removal will open new export opportunities for Canadian businesses to major markets such as Japan, Malaysia and Vietnam.More significant technical needs will make it easier for Canadian producers in all manufacturing sectors to trade boundaries. The CPTPP Technical Obstacles to Trade (TBT) chapter completes agreed tariffs and approvals, to create a more predictable environmental trade for partners at CPTPP. This will inform producers and 
Open Access at: http://ojs.uho.ac.id/index.php/PUBLICUHO/index

exporters in the prospective market. Minimising the impact of technical constraints will help maximise market access for Canadian exports. The provisions contained in this provision will help streamline agreements, make more transparent regulations and increase property rights.(Office of the Chief Economist Global Affairs Canada, 2018b).

\section{Market Expansion}

Two important regions in Canadian focus to trade are Europe and the Asia Pacific. In Europe, the United States has formed a regional partnership called the Comprehensive Economic and Trade Agreement (CETA), where Canada, together with the European Union collaborates to strengthen relations and improve the economy. While in the Asia Pacific region, Canada joined regional economic cooperation, namely APEC so that the joining of Canada in CPTPP will strengthen Canada's relations with Asia-Pacific countries by conducting trade relations both for export, import and investment.

Indonesian Consulate General of Toronto Canada, Leonard Felix Hutabarat stated :

"with the many free trades that Canada is taking part in, it will strengthen Canada's global trade worldwide. For now, Canada is the only G7 country that has free trade agreements with all other G7 members so that Canada can expand access to free trade in all regions such as America, Europe and the Asia Pacific region"(Hutabarat, 2019)

CPTPP, USMCA and CETA make Canada the only G7 country that has free trade agreements with all other G7 members who give Canada free trade access throughout America, Europe and the Asia Pacific region. That is, there is an opportunity to position Canada as a global trade centre with privileged access throughout Asia, Europe and America.

Canada is making stronger gains in the Asia Pacific market by expanding trade markets because it does not have to share the benefits of trade liberalisation with the United States after the United States exits the TPP. The potential that CPTPP has for Canada for market expansion is at least in several things. First, some CPTPP countries are important export markets for Canada. CPTPP provides an opportunity to expand trade relations with these countries. Japan is a substantial market for agriculture and agri-food products, but this country has historically been very protective for this product with imposing high tariffs and other import restrictions. CPTPP will remove these trade barriers, which will ultimately bring economic benefits to Canada. Second, CPTPP will create opportunities in emerging markets (Vietnam, Singapore and Malaysia). The economy is expected to develop at a rate higher than $4 \%$. Trade agreements with these countries will create opportunities for Canada to gain preferential access to these markets with high demand for consumer and producer goods and services. Third, the Organization for Economic Co-operation and Development (OECD) and the Food and Agriculture Organization of the United Nations (FAO) revealed that global 
consumption of beef and wheat is expected to increase by an annual average of $11 \%$ in 2023.

Meanwhile, consumption for these products in some CPTPP countries (Chile, Malaysia and Peru) are projected to increase by $20 \%$. These agricultural products are essential for Canada preferential market access will increase Canadian exports. Fourth, CPTPP will increase domestic competition due to the presence of competitive partners such as Australia and New Zealand, consequently resulting in increased efficiency of the local market. Canada may be able to rely on the CPTPP agreement to increase access to foreign markets, especially the more significant and protected Japanese market. CPTPP will also allow Canada to benefit from its competitive advantage in the markets of member countries compared to other exporters.

\section{CONCLUSION}

The Comprehensive and Progressive Agreement for the Trans-Pacific Partnership (CPTPP) offers economic incentives for countries that sign the Agreement. In this Agreement, Canada has the vision to enhance the economic growth of the countries. Canada's policy to ratifying the CPTPP agreement is due to economic interests. First, Canada diversified its export markets to reduce its significant dependence on the United States market. Second, enhancing and maintaining market access in the Asia Pacific Region through tariff removal in the CPTPP Agreement. And Third from market expansion, Canada now stands to make stronger profits in the Asia-Pacific because it does not have to share the benefits of trade liberalisation with the United States. 


\section{Bibliography}

Aisyah, R. (2018). Keikutsertaan Kanada dalam Perjanjian Trans-Pacific Partnership : Sebuah Analisis Liberal Intergovernmentalism. Jurnal Transformasi Global, 3.

Anjani, A. R. (2018). Kepentingan Amerika Serikat Keluar dari Trans Pacific Partnership dimasa Pemerintahan Donald Trump. Jurusan Ilmu Hubungan Internasional-Prodi Hubungan Internasional Fakultas IImu Sosial Dan IImu Politik Universitas Riau, 5(I), 1-14.

Balaam, D. N., \& Veseth, M. (2005). Introduction to International Political Economy (3rd ed.). New Jersey: Pearson Education Inc.

Brown, C. (2005). Understanding International Relations (3rd ed.). New York: Palgrave Macmillan.

Ciuriak, D., Xiao, J., \& Dadkhah, A. (2017). Quantifying the Comprehensive and Progressive Agreement for. East Asian Economic Review, 21 (4), 343-384.

CNN Indonesia. (2017). Trump Bawa AS Resmi Keluar dari TPP. Retrieved February 14, 2019, from https://www.cnnindonesia.com/internasional/20170124011942-134-188433/trumpbawa-as-resmi-keluar-dari-tpp

Cossa, B. R. A., Glosserman, B., Mcdevitt, M. A., Patel, N., Przystup, J., Roberts, B., ... Cronin, P. (2009). The United States and the Asia-Pacific Region: Security Strategy for the Obama Administration. Retrieved from https://csis-prod.s3.amazonaws.com/s3fspublic/legacy_files/files/media/csis/pubs/issuesinsights_v09n01.pdf

Elms, D., \& S, Lim, C. . L. . (2012). The Trans-Pacific Partnership Agreement ( TPP ) Negotiations: Overview and Prospects About RSIS.

Estrada, J. S. N. (2016). The Trans-Pacific Partnership_ Understanding the Economic Impact for Mexico and Canada. Retrieved August 23, 2019, from redalyc.org website: https://www.redalyc.org/jatsRepo/4337/433753436003/html/index.html

Goodman, M. P. (2018). From TPP to CPTPP. Retrieved from Center for Strategic and International Studies website: https://www.csis.org/analysis/tpp-cptpp

Hutabarat, L. F. (2019). Interviewed.

International Monetary Fund (IMF). (2017). World Economic Outlook Database April 2017.

Leong, B. (2018). CPTPP - WHAT DOES IT MEAN FOR SEA'S SMES AND ECOMMERCE? Retrieved July 27, 2019, from Janio.asia website: https://janio.asia/articles/cptpp-sme-1/

Miles, M. B., \& Huberman, M. A. (2007). Qualitative Data Analysis (terjemahan). Jakarta: UI Press.

Mukhopadhyay, K., \& Thomassin, P. J. (2018). The impact of Trans - Pacific Partnership agreement on the Canadian economy. Journal of Economic Structures. https://doi.org/10.1186/s40008-017-0102-y

Nuechterlein, D. E. (1976). National interests and foreign policy: A conceptual framework for analysis and decision-making. British Journal of International Studies, 2, 246-266.

Office of the Chief Economist Global Affairs Canada. (2018a). Economic impact of Canada's participation in the Comprehensive and Progressive Agreement for Trans-Pacific Partnership. Retrieved July 18, 2017, from https://www.international.gc.ca/tradecommerce/trade-agreements-accords-commerciaux/agr-acc/cptpp-ptpgp/impact- 
repercussions.aspx?lang=eng

Office of the Chief Economist Global Affairs Canada. (2018b). What does the CPTPP mean for industrial goods_. Retrieved July 12, 2019, from Canada.ca website:

https://www.international.gc.ca/trade-commerce/trade-agreements-accordscommerciaux/agr-acc/cptpp-ptpgp/sectors-secteurs/industrialindustriels.aspx?lang=eng\&_ga=2.174686562.1563149761.15712771111214943607.1571277111

Office of the Chief Economist Global Affairs Canada. (2018c). What does the CPTPP mean for the fish and seafood sector_. Retrieved July 27, 2019, from Canada.ca website: https://www.international.gc.ca/trade-commerce/trade-agreements-accordscommerciaux/agr-acc/cptpp-ptpgp/sectors-secteurs/fishpoisson.aspx?lang=eng\&_ga=2.174686562.1563149761.15712771111214943607.1571277111

Office of the Chief Economist Global Affairs Canada. (2018d). What does the CPTPP mean for the forestry sector_. Retrieved June 28, 2019, from Canada.ca website:

https://www.international.gc.ca/trade-commerce/trade-agreements-accordscommerciaux/agr-acc/cptpp-ptpgp/sectors-secteurs/forestryforesterie.aspx?lang=eng\&_ga=2.1746866562.1563149761.15712771111214943607.1571277111

Office of the Chief Economist Global Affairs Canada. (2019). CPTPP and Canada's Agriculture and Agri-food Sector. Retrieved June 27, 2019, from Canada.ca website: https://www.international.gc.ca/trade-commerce/trade-agreements-accordscommerciaux/agr-acc/cptpp-ptpgp/sectorssecteurs/agri.aspx?lang=eng\&_ga=2.174686562.1563149761.15712771111214943607.1571277111

The Straits Times. (2017). Trans-Pacific Partnership deal moves ahead without US. Retrieved August 18, 2019, from Strautstimes.com website: https://www.straitstimes.com/world/tppdeal-moves-ahead-without-us

Yen, P. T. H. (2017). Welcoming the Comprehensive and Progressive Agreement for TransPacific Partnership Agreement (CPTPP) -Vietnam continue to promote broader international economic integration. Retrieved from https://www.freit.org/WorkingPapers/Papers/TradePolicyMultilateral/FREIT1301.pdf 